
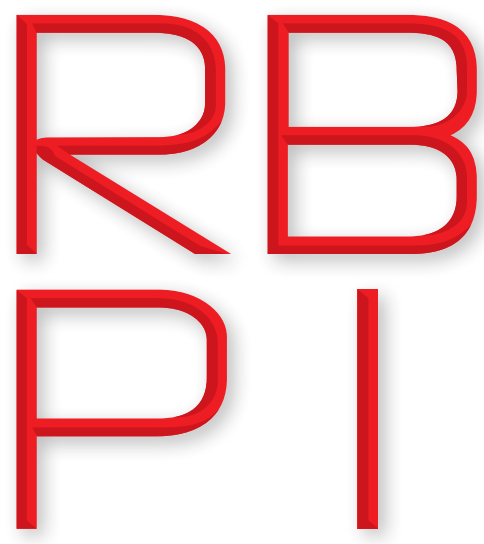

Revista Brasileira de Política Internacional ISSN 1983-3121

http://www.rbpi.info

\section{Fernanda Barasuol}

Universidade Federal do Rio Grande do Sul, Faculdade de Economia, Porto Alegre - RS, Brazil (febarasuol@gmail.com).

iD ORCID ID:

orcid.org/0000-0003-2368-8226

\section{André Reis da Silva}

Universidade Federal do Rio Grande do Sul, Faculdade de Economia, Porto Alegre - RS, Brazil (reisdasilva@hotmail.com).

(iD)

ORCID ID:

orcid.org/0000-0003-2593-1189

\section{Copyright:}

- This is an open-access article distributed under the terms of a Creative Commons Attribution License, which permits unrestricted use, distribution, and reproduction in any medium, provided that the original author and source are credited.

- Este é um artigo publicado em acesso aberto e distribuído sob os termos da Licença de Atribuição Creative Commons, que permite uso irrestrito, distribuição e reprodução em qualquer meio, desde que o autor e a fonte originais sejam creditados.

\section{International Relations Theory in Brazil: trends and challenges in teaching and research}

DOI: http://dx.doi.org/10.1590/0034-7329201600205

Rev. Bras. Polít. Int., 59(2): e005, 2016

\section{Abstract}

This article presents a preliminary analysis of the teaching of International Relations Theory (IRT) and the use of theory in Brazilian academic research. We evaluate the teaching of IRT by analyzing courses' curricula and syllabi. Our analysis of the use of IRT in Brazilian research is based on Doctoral dissertations, CNPq-funded technical reports and papers published in Brazilian journals.

Keywords: International Relations Theory; International Relations teaching; Research; knowledge production; Brazil.

Received: September 29, 2015

Accepted: June 13, 2016

\section{Introduction}

$\mathrm{n}$ the field of International Relations, there is an
undeniable predominance of American and European theoretical perspectives ${ }^{1}$. Surrounded by "gates" and "gatekeepers" IR remains "indifferent to scholarly practices and policy issues outside the core" (Tickner and Blaney, 2012: 1). This state of affairs has generated a response from scholars who have tried to both understand the reasons behind this predominance and increase the discipline's inclusiveness by bringing in scholarship from outside the core.

Despite these efforts, the issue of "why is there no nonWestern international theory?" (Acharya and Buzan, 2010) remains. Much of the literature on this topic focuses on the barriers imposed upon the intellectual production and circulation of ideas from other parts of the world. While these barriers are important, it is also necessary to consider how theoretical and methodological reflection in the field of IR takes place outside of the core.

1 See, for example: WEAVER, Ole. (1998); SMITH, Steve. (2000); AYNDILI and MATHEWS (2000); ACHARYA and BUZAN (2010). 
Theory is an incredibly important tool for understanding the world. It helps us find patterns in reality and see single events beyond their more obvious reasons and consequences (Acharya and Buzan 2010: 4). In sum, through theory we understand events, rather than simply memorize facts. Theory can also guide practice by providing road maps for policymakers (Goldstein and Keohane, 1993) - and better maps can lead to better policymaking. In research, theory is crucial. As Mearsheimer and Walt (2013: 430) put it: "Because the world is infinitely complex, we need mental maps to identify what is important in different domains of human activity."

Much has been said about the kinds of barriers authors outside the core face when attempting to publish their work. However, it is also important to look at how much attention theory receives outside the core, both in teaching and research. The lack of attention paid to theory and methodology in IR teaching may influence the quality of the research in the field, contributing to a vicious cycle of intellectual dependency which limits the development of the discipline. Furthermore, it affects the quality of public debate with consequences for relevant policy actors. As Hagmann and Biersteker (2014: 292) argue "the analytical horizons [...] of civil servants [and] IR scholars are, at least in their early years of career, significantly determined by the perspectives taught in IR courses". Lack of attention to theory also limits Brazil's potential contribution to the diversification of centers of theory production.

This paper presents a preliminary and qualitative analysis of the teaching of International Relations Theory (IRT) and the use of theory in research in the field of IR in Brazil. This is clearly a limited objective, which we justify by the lack of empirical data available or previous works on the relation between teaching of IRT and research which to build upon. We chose Brazil as a case study because of the enormous growth of the field of IR in the country in the last fifteen years, which has been concomitant with a growth in the international role and visibility of Brazilian diplomacy.

This paper is divided into three sections. The first section briefly describes the development of the field of International Relations in Brazil, both in the undergraduate and graduate levels. In the following section we use course curricula and syllabi to analyze the teaching of IRT in Brazilian universities. In the final section we study $\mathrm{PhD}$ dissertations, technical reports from research financed by the National Council for Scientific and Technological Development (CNPq) and papers from the two top Brazilian IR journals to understand how theory is used in research.

\section{The Development of the Field of International Relations in Brazil}

The International Relations discipline, as an independent field of study, had a relatively late development in Brazil. Prior to the 1970s, the study of IR received very little attention. Up to this point most of the studies were related to Brazilian policies for the La Plata Basin and the country's relations with Argentina. For the most part these were of a geopolitical nature and were often written by the military or by diplomats (Herz, 2002; Miyamoto, 1999). Monica 
Herz (2002: 15) indicates as factors for this low development of IR in Brazil at the time "the relation between the reflection on foreign policy [and] the diplomatic apparatus, an inexpressive international role and a clear connection with United States' international politics".

In the 1970s, the study of International Relations gained momentum in Brazil, although its progress was slow. The discipline faced difficulties due to the small number of academics who specialized in IR and the military regime's censorship. However, it was in this decade that the first university program was created at the University of Brasilia (UnB) in 1974, as well as the Brazilian Counsel of International Relations in 1978, and the Institute of International Relations of the Catholic University of Rio de Janeiro (PUC-Rio) in 1979 (Herz, 2002; Miyamoto, 1999).

A controversial aspect regarding the development of the field in Brazil is its association with Political Science. Some authors (Herz, 2002; Lessa, 2005; Julião 2009) argue that IR in Brazil did not stem from Political Science, as it did in the United States and Germany. It emerged, instead, from the contributions of specialists from several fields, such as History, Political Science, Economy and International Law. This configuration resulted, according to this view, from the late development of Political Science itself, which only became an independent discipline in Brazilian universities in the mid-1960s. Other authors, however, believe that the field of IR in Brazil was created "in an intimate association with Political Science” (Mendonça; Velasco e Cruz, 2010:298).

Evidence seems to point towards different trajectories of development in different institutions - some closer to Political Science, others to History- but with a predominance of a broad multidisciplinarity, which includes not only those disciplines but also Law, Economics and Geography. An analysis of the curriculum vitae of the faculty of IR departments at 18 institutions ${ }^{2}$ exposes this diversity: $20.5 \%$ of professors have their master's degrees in IR, $14.5 \%$ in History, 20\% in Political Science, 13\% in Economics, 7\% in Law, 8.5\% in Sociology, and the remaining $17 \%$ in other fields (which include Geography, Philosophy and even Engineering). The numbers are virtually the same when it comes to $\mathrm{PhD}$ degrees, though with a higher representation of Political Science (26.5\%), which might be explained by the still small number of IR PhD programs in Brazil.

The diversity between different institutions also becomes apparent: The University of Brasilia (UnB), host of the country's oldest undergraduate program in IR, has by far the most professors with undergraduate degrees in IR (50\%). Programs which are hosted in Schools of Economics, such as those of the Federal University of Rio Grande do Sul (UFRGS) and the Federal University of Santa Catarina (UFSC), have a good portion of their faculty with degrees

2 For this analyses we opted to use the curriculum of professors in all public Universities and private universities that have graduate programs in IR, since these institutions are responsible for producing most of the research in the field. The universities analyzed were: University of Brasilia, Federal University of Sergipe, Federal University of Uberlândia, University of São Paulo, State University of Paraíba, Federal University of Rio Grande do Sul, Federal University of Santa Maria, Federal University of Santa Catarina,_Federal University of Latin American Integration, Federal University of São Paulo, Federal University of the Pampa, State University of São Paulo, Federal University of Pelotas, Fluminense Federal University, PUC Rio de Janeiro, PUC Minas, Federal University of Bahia and State University of Rio de Janeiro. The Federal University of Rio de Janeiro and the Federal University of Grande Dourados did not have a list of faculty members available online. 
in that field. At the Catholic University of Rio de Janeiro, (PUC Rio), which is known as a hub for post-positivist IRT, two thirds of the faculty have PhDs in IR.

The growth of the field of International Relations in Brazil effectively took off in the 1990s, when many undergraduate and graduate programs were created. Since then the expansion has been impressive, as shown in Graph 1.

\section{Graph 1: Number of Programs offering IR undergraduate degrees in Brazil (1995-2015)}

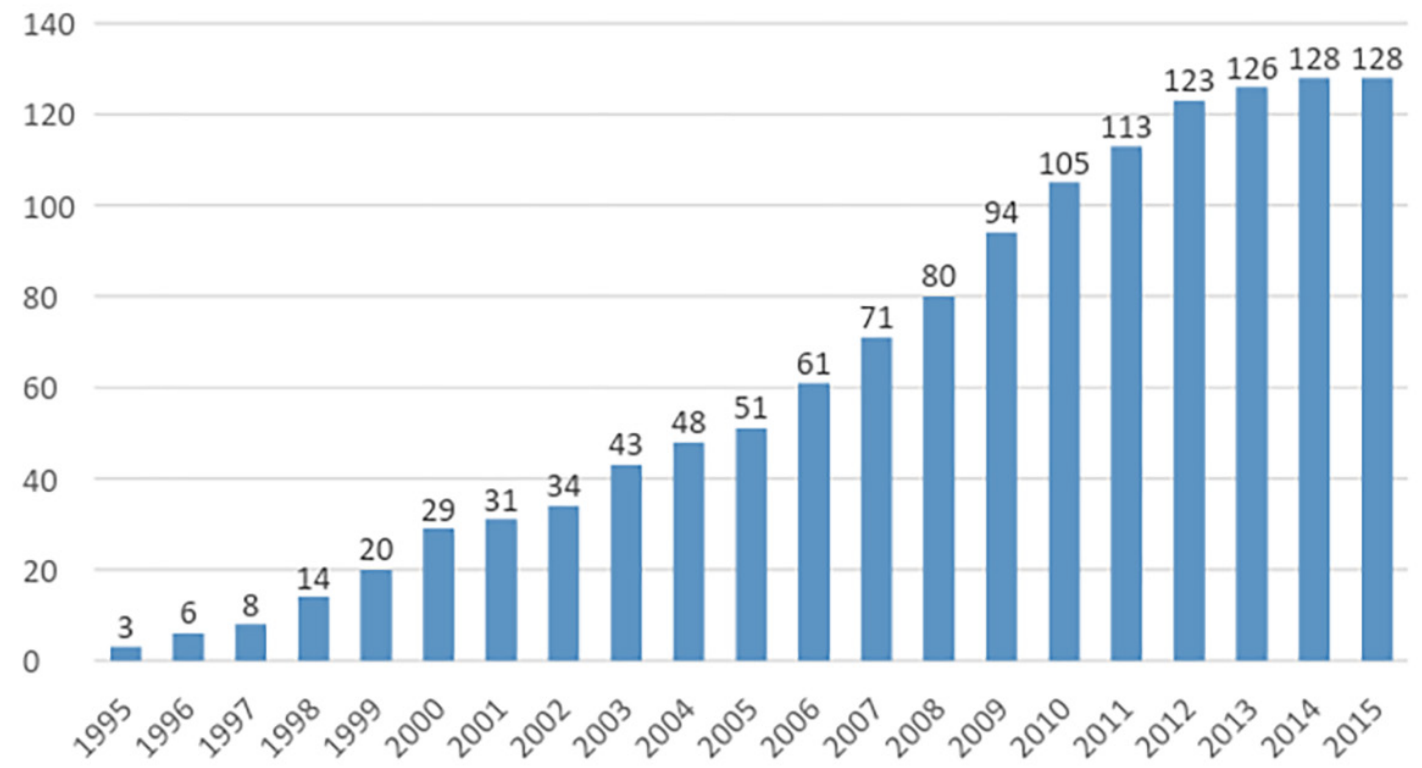

Source: Authors' own elaboration based on data provided by the Brazilian Ministry of Education (MEC).

Note: Includes only programs that were recognized by the Ministry of Education (MEC) and which had the date of creation available, which excluded five programs (they are: UNIPLAN, IBMEC Distrito Federal, Faculdade Michelangelo, FRB-GV and Estacio BH). Does not include on-line programs.

As shown, the number of undergraduate degrees ${ }^{3}$ multiplied manifold in the 1990 s and 2000s. Until the second half of the 1990s only three universities offered IR undergraduate degrees in Brazil. Ten years later this number had grown to 50, and in the following seven years it more than doubled. An important incentive for this growth was the increase in job opportunities in several areas, such as international organizations and consulting firms. The increased relevance of Brazil in the International System was also a factor.

The growth of the field of IR took place concomitantly with the growth of universities in general. As can be seen in Graph 2 (below) higher education in Brazil expanded considerably between 2000 and $2012^{4}$, with the creation of a large number of new undergraduate programs.

3 We decided to use the term "degree" as an equivalent for the Brazilian "curso", and "course" as the equivalent for "disciplina". These are most common terms in the United States. However, we understand that there are differences even among English-speaking countries. Our "degrees" here correspond to British "courses", and our "courses" to British "modules".

4 INEP only has available data for higher education as a whole until 2012. 
Graph 2: Growth of undergraduate programs in IR and growth in higher education in all fields (2000-2012)

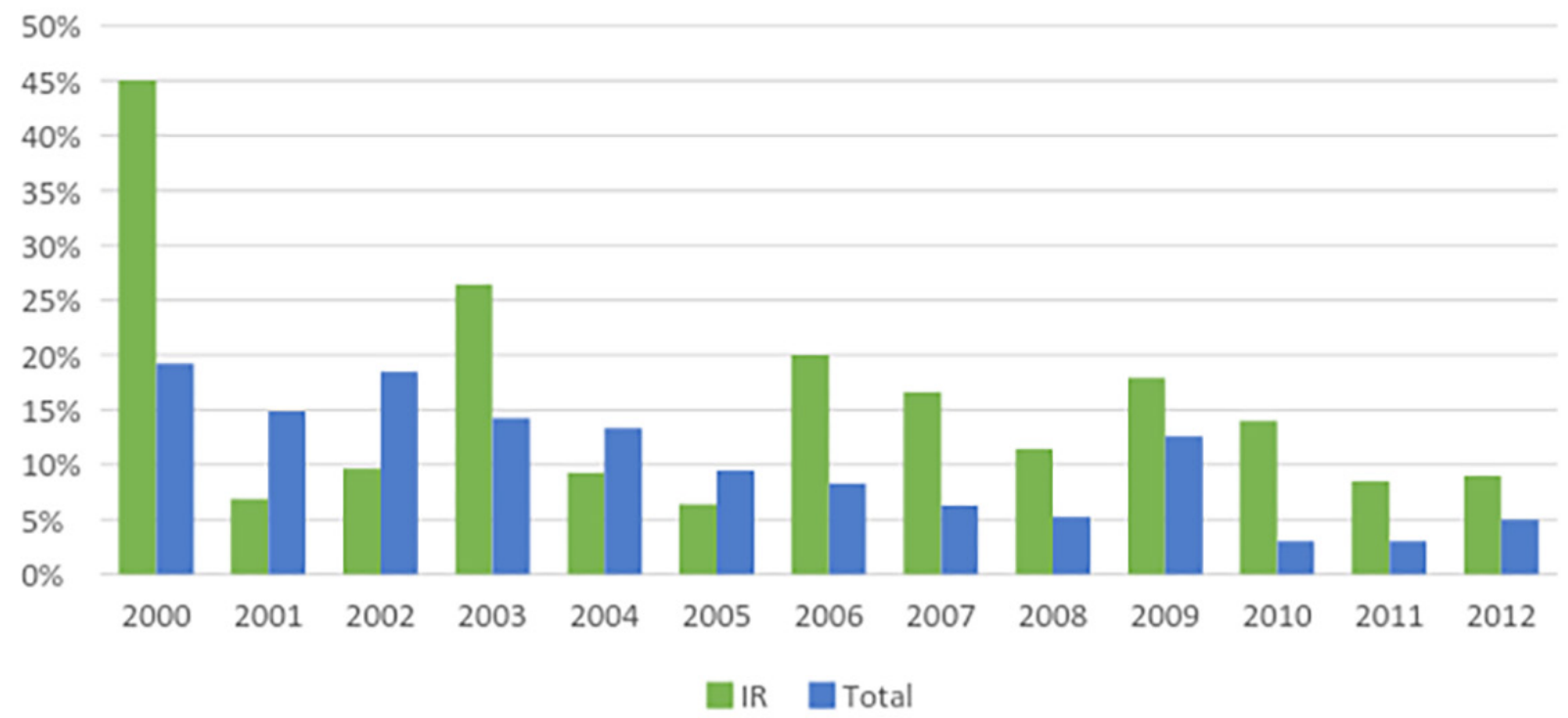

Source: Authors' own elaboration based on data provided by the Ministry of Education (MEC) and the National Institute of Studies and Educational Research (INEP).

If we consider the whole period, the number of undergraduate programs as a whole grew by $190 \%$, while the number of IR programs grew by $324 \%$. However, it must be taken into account that there were only 20 IR undergraduate programs in 1999.

It is also noteworthy that the expansion of the field of International Relations was much more irregular, with great peaks in some years $(2000,2003)$ and more modest growth rates in others $(2001,2002,2004,2005)$. Comparatively, the growth in higher education as a whole was more uniform, though with higher rates in the 1999-2003 period than subsequently.

The growth in the field of IR was also very unequal in geographical terms, becoming concentrated in the South, in the Southeast (especially in São Paulo) and in the Federal District. Out of the 126 undergraduate programs accredited by the Ministry of Education (MEC), 42 are in São Paulo, 21 in Rio de Janeiro, 20 in the Federal District (Brasilia), 14 in Rio Grande do Sul, 8 in Santa Catarina, 7 in Paraná, 6 in Minas Gerais, 3 in Pernambuco, Amazonas, Bahia, Mato Grosso do Sul and Paraiba have 2 courses each, Amapá, Ceará, Espírito Santo, Goiás, Pará, Rio Grande do Norte, Roraima and Sergipe each have one, and the other states have none.

Another important aspect regarding the configuration of IR undergraduate studies in Brazil is the predominance of private universities ${ }^{5}$. In 2009, 83. 7\% of degrees were offered by private institutions, and only $16.3 \%$ by public universities (Julião, 2009). For the sake of comparison, in the same year, the private sector comprised only $54 \%$ of higher education as a whole (INEP, online). This means that the participation of private institutions in IR is some $30 \%$

5 It is worth noting that most private institutions in Brazil are for-profit. According to data from the Ministry of Education (online) in 2004 only $30 \%$ of private universities were non-profit institutions. 
higher than the average for higher education. Furthermore, of the 112 public universities in Brazil, only 18 offer undergraduate degrees in IR.

Graduate programs in IR also expanded considerably in recent years. Although the first programs were created in the 1980s (at UnB and PUC Rio), most of the masters and PhD programs existing today are quite new, having only been created in the 2000 s.

\section{Table 1: International Relations Graduate Programs in Brazil}

\begin{tabular}{|c|c|c|c|}
\hline University & Degree & Level & Year Created \\
\hline University of Brasilia (UnB) & International Relations & M D & 1985 and 2002 \\
\hline Catholic University of Rio de Janeiro (PUC-Rio) & International Relations & M D & 1987 and 2001 \\
\hline University of São Paulo (USP) & International Relations & M D & 2002 and 2008 \\
\hline $\begin{array}{l}\text { São Paulo State University (UNESP), } \\
\text { Catholic University of São Paulo (PUC SP) and } \\
\text { University of Campinas (UNICAMP) - San } \\
\text { Tiago Dantas }\end{array}$ & International Relations & M D & 2003 and 2011 \\
\hline $\begin{array}{l}\text { Rio de Janeiro University Institute of Research } \\
\text { (IUPERJ) }\end{array}$ & Political Science and International Relations & M D & 2011 \\
\hline Federal University of Santa Catarina (UFSC) & International Relations & M & 2011 \\
\hline Federal Fluminense University (UFF) & Strategic and Defense Studies & M & 2008 \\
\hline Rio de Janeiro State University (UERJ) & International Relations & M & 2008 \\
\hline State University of Paraíba (UEPB) & International Relations & M & 2009 \\
\hline Federal University of Rio Grande do Sul (UFRGS) & International Strategic Studies & M D & 2011 \\
\hline Catholic University of Minas Gerais (PUC MG) & International Relations & M D & 2007 and 2011 \\
\hline $\begin{array}{l}\text { Federal University of Latin-American Integration } \\
\text { (UNILA) }\end{array}$ & $\begin{array}{l}\text { Contemporary Latin-American } \\
\text { Integration }\end{array}$ & M & 2014 \\
\hline Federal University of Bahia (UFBA) & International Relations & M & 2014 \\
\hline Federal University of Uberlandia (UFU) & International Relations & M & 2015 \\
\hline
\end{tabular}

Source: Authors' own elaboration based on data provided by the Coordination for the Improvement of Higher Education Personnel (CAPES) and by the mentioned universities.

Notes: M corresponds to Masters and D to PhD. For IUPERJ we considered the dates of reopening after the restructuration process.

Besides those included in the table above, there are also graduate programs in Political Science that have field concentrations in IR. USP has a research concentration in International Relations; UNICAMP, in International Studies (within the field of Contemporary Politics); UFPR in Brazilian Foreign Policy and International Organizations; UFMG in International and Comparative Politics; UFRGS and UFPE in International Politics, and UERJ in International Politics and Foreign Policy Analysis.

It is also noteworthy that of the seven $\mathrm{PhD}$ programs, five were established in the last five years. As Santos (2009: 279) points out, the growth in graduate programs is related to 
the demand for professors which resulted from the expansion of the number of undergraduate programs. In this context, the growth in the number of $\mathrm{PhDs}$ in the field is required for the qualification of the teaching and research in IR in the country.

Unlike undergraduate education, in graduate programs public institutions are a majority. Considering the 14 universities that offer masters or $\mathrm{PhD}$ degrees in IR, ten are public, three are private, and one is a partnership between two public universities and a private one. This reflects in a greater participation of public institutions in IR academic research in Brazil.

Despite the recent growth in the field, there are still problems in IR teaching and research that have not been addressed. Lessa (2007), for example, points out that despite this growth, IR in Brazil is still largely underdeveloped compared to other Latin American countries, notably Argentina and Mexico. Julião (2009: 106) argues that "the multidisciplinary character of the curricula does not form professionals with a defined profile". Similarly, Miyamoto (1999) highlights a tendency, oftentimes excessive, to make courses more "practical", focusing on aspects that are more related to international trade. These factors certainly have an influence on the role of IRT teaching, and how this teaching is done, as will be shown in the next section.

\section{The Teaching of International Relations Theory in Brazil}

The efforts towards pragmatism have a significant effect on how undergraduate curricula are designed. Given that theory is largely perceived as something inherently academic, with little applicability to "real life" and with little connection to the issues students will face in their future careers, the general trend is to have few International Relations Theory courses and for these courses to be detached from the rest of the curriculum. The lack of consensus regarding the expected profile of those who graduate in IR also contributes to the fact that the emphasis given to IRT varies greatly among different institutions - not only in relation to the amount of disciplines, but also their content.

It is important to highlight, however, two factors that were crucial in increasing the interest in IRT in Brazil. Firstly, the existence of autonomous reflection about the social-economic development and the international position of Brazil, which precedes the institutionalization of IR as a discipline in the country ${ }^{6}$. Secondly, the effort of Brazilian professors in formulating

\footnotetext{
6 Although it would not be possible to mention all those authors here, we would like to name a few who have made important contributions to this reflection. We would like to bring attention the work of Caio Prado Jr, who sought to understand Brazilian development through its position as a colony; to the authors at CEPAL, who developed a set of theoretical tools, such as the concepts of core and periphery, that aid in comprehending the historical development of capitalism as a whole; the Theory of Dependency - whose main proponents are Fernando Henrique Cardoso (in a partnership with Enzo Faletto) and Theotonio dos Santos - which is recognized by some as the first genuinely peripheral school of thought devoted to the understanding of the international insertions of underdeveloped countries (Tickner, 2003). The work of Helio Jaguaribe, which is dedicated mostly to the matter of the autonomy of States; in a similar manner, Samuel Pinheiro Guimarães sought to analyze the structure of the International System through an independent optic, which privileges the peripheral reality; and finally, the work of Professor Amado Cervo, especially his contribution to the study of Brazilian foreign Policy (Herz, 2002; Tickner, 2003; Cervo, 2008).
} 
good quality manuals and introductory texts to be used in undergraduate courses, such as the works of Pecequilo (2005), Nogueira and Messari (2005), Silva and Gonçalves (2005), Cervo (2008), and Medeiros, Lima, Villa and Reis (2010) ${ }^{7}$. Besides that, there were also instrumental works of research investigating the teaching in other subfields of IR, such as the study conducted by Santos (2005) on the teaching of History of International Relations, and the study made by Faria (2012) on teaching and research in Foreign Policy Analysis.

In order to analyze how the teaching of IRT is conducted in Brazil, we analyzed 83 curricula from undergraduate courses in International Relations ${ }^{8}$. Our first objective was to discover how many IRT disciplines were offered ${ }^{9}$. Out of the 83 , only four did not offer any IRT courses (Unisul, UMC, UNP and La Salle Manaus), which represents 4.8\% of the total. The average number of disciplines offered was 1.85 . The universities which offer the highest number of IRT disciplines are FACAMP (four mandatory disciplines) and PUC Rio (three mandatory disciplines). It is also noteworthy that most institutions do not offer any optional disciplines related to theory.

Our second step was to analyze qualitatively the syllabi of IRT courses offered in 31 universities ${ }^{10}$. The objectives were to analyze which contents were emphasized, and what bibliography was recommended, as well as determine which Schools of Thought were predominant in the mandatory readings ${ }^{11}$.

The first characteristic observed was that most courses tend to emphasize the presentation of the various theoretical schools, with little or no time dedicated to an ampler debate regarding the formulation of theories or their utility for the development of research. Of the analyzed

7 The approach adopted by Cervo (2008) in his work Inserção Internacional: formação de conceitos brasileiros is different, since its goal is not to present the traditional IR theories. The author seeks, rather, to show Brazilian works in the field of IR, illuminating their dialogue with traditional IR Schools of Thought and developing his own concepts about Brazil's international insertion.

8 The debate regarding what, exactly, constitutes a theory, has been a central one in the field of IR in the past decades. It is necessary to make clear, therefore, from the beginning, the position adopted in this paper. Given that this a preliminary analysis, which does not intend to evaluate on a deeper level how theories have been used in research, we have opted for a neutral position, adopting as general criteria what the professors (for teaching) and authors (for research) consider theory. This position is close to that proposed by Barry Buzan e Amitav Acharya (2010: 6) who list the following criteria: "that it be substantially acknowledged by others in the IR academic community as being theory; that it be self-identified by its creators as being IRT even if this is not widely acknowledged within the mainstream academic IR community; that regardless of what acknowledgment it receives, its construction identifies it as a systematic attempt to generalize about the subject matter or IR."

9 We analyzed all the curricula that were available in the websites of the universities. Besides those universities which did not have their curriculum available online, the number decreased because some institutions used the same curriculum for all its subsidiaries.

10 The course syllabi were obtained mostly by direct contact with either the program administration or the professors. We used in this research the syllabi from the following universities: UNB, UNICEUB, PUC GOIAS, UFGD, PUC MINAS, UNI-BH, UFPB, UTP, UNICURITIBA, UNINTER, Bennett, PUC RJ, UNISINOS (only the syllabus for IRT I, since IRT II had not yet been offered), UNISC, UNIRITTER, UFRGS, UFSM, UFPEL, Faculdade América Latina, FAACS, UNIPAMPA, UFRR, UFSC, USP, UNESP, UNAERP, FMU, PUC SP, UNIFESP (only the syllabus for IRT I, since IRT II had not yet been offered), FACAMP, e SENACP-SP.

11 In this work we opted for the use of the term "Schools of Thought" in International Relation as an analysis unit. This is the concept which is closest to the 'isms' (Realism, Liberalism, Constructivism) and was chosen especially because the IRT syllabus ten to be organized around these 'isms', which not only makes our analysis easier, but also the comparison between teaching and research. This unit, however, is not a consensus in the study or evaluation of theory in IR. Some authors prefer to use the term Research Programs, the unit proposed by Lakatos, which would include, apart from the 'isms', programs such as 'democratic peace' or 'power transition'. Others still prefer the use of Paradigms, the unit used by Kuhn. (ELMAN e ELMAN, 2003). 
syllabi, 56\% do not dedicate any part of the course(s) to this kind of debate (that is, it is not present as a part of the syllabus); other $26 \%$ have a specific topic dedicated to these matters, but use as its bibliography only the introductory chapter of manuals, and only $16 \%$ recommend any readings beyond manuals which relate specifically to the development of theories or its relations to the conduct of research.

Regarding the recommended bibliography, most courses (80\%) use as part of their required readings ${ }^{12}$, besides manuals, original texts. However, in most cases these texts are restricted to one or two works from renown authors, the most used being Raymond Aron, Ernst Haas, Hans Morgenthau and Kenneth Waltz.

A decisive factor for this is possibly the fact that a significant part of the works of IRT has not been translated into Portuguese. If we take the 13 most influential authors in the field of IR, according to the Teaching, Research and International Policy survey (online) ${ }^{13}$, only seven of those have works translated to Portuguese, and two of those translations are from Portugal. One of the authors, James Fearon, has only published journal articles or chapters in books, which highlights another problem: besides the language barrier, there is an additional, monetary barrier. This is especially the case in private universities that do not always have access to the government's subscription to academic journals ${ }^{14}$. When it comes to post-positivist and critical authors the translations are even more scarce: we searched for translations of six well known authors and could only find one translated work ${ }^{15}$.

To verify the influence of different theories in the study of International Relations in Brazil, we opted to use a methodology similar to that proposed by Arlene Tickner (2003). Like Tickner, we based our analysis on the texts indicated in the syllabus as mandatory readings, and classified them in different categories in order to verify their relative weight. However, we chose to classify them according to the different theoretical Schools of Thought- that is, in the same manner they are usually classified in the syllabi themselves. Tickner (2003) had opted to classify the texts according to categories developed by the author herself (Classical state-centric, Classical non-state-centric, General Classical, Marxist/neo-Marxist, Post-modern, Constructivist, Latin American Hybrid, Foreign Policy Analysis, and Other). Also unlike the author we decided to use the syllabi from all the theory courses offered (and not just the introductory courses), given that the theories tend to be divided between two or more courses, and that this division is often chronological.

12 We decided to not include the optional texts in our analysis, assuming that the required reading better represents what students in fact read in what is debated in the classroom.

13 We combined the authors considered the most influential in the international faculty survey with three additional authors that are present in the Brazilian faculty survey (they are: Alexander Wendt, Robert Keohane, Kenneth Waltz, John Mearsheimer, Joseph Nye Jr., Samuel Huntigton, Barry Buzan, James Fearon, Stephen Walt, Martha Finnemore, Robert Cox, Nicholas Onuf and Fred Halliday). The authors who have been translated to Portuguese are: Wendt, Waltz, Mearsheimer, Nye, Huntington, Buzan and Halliday.

14 To have access to that subscription (the CAPES Portal) a private university must have at least one masters or one PhD program with a higher than average ( 4 for masters and 5 for $\mathrm{PhD}$, out of 7 ) quality rating from the government.

15 The six authors are: Andrew Linklater, Cynthia Weber, David Campbell, R.B.J Walker, Cynthia Enloe and Ann Tickner. Only R. B. J Walker had been translated. 
Some brief comments regarding the classification of the texts are necessary. In those courses where the bibliography was distributed according to the different contents studied the classification was quite simple: since these points normally converge with the different theories all that was necessary was to count them and distribute them ${ }^{16}$. In the syllabi where the whole bibliography was presented at the end the process was similar, the only difference being that the classification into different theories was done by the authors. Finally, in the syllabi that used only a manual as a mandatory reading, we sought to respect the weight given by the manual itself to each theory. In these cases, each chapter in the manual was counted as a "text" so that if the manual had, for example, two chapters dedicated to Realism and one to Constructivism this would be the number of texts allocated to each School of Thought.

Table 2: International Relations Theories in Required Readings for IRT courses

\begin{tabular}{|l|c|}
\hline Realism & $17 \%$ \\
\hline Liberalism & $11 \%$ \\
\hline Neorealism & $12 \%$ \\
\hline Neoliberalism & $13 \%$ \\
\hline Constructivism & $9 \%$ \\
\hline English School & $8 \%$ \\
\hline Marxism & $9 \%$ \\
\hline Feminism & $4 \%$ \\
\hline Critical Theory & $5 \%$ \\
\hline Post-modernism & $5 \%$ \\
\hline Latin American Thought & $2 \%$ \\
\hline Other & $5 \%$ \\
\hline
\end{tabular}

Source: Authors' own elaboration based on syllabi from 31 IRT courses offered in Brazilian Universities.

Table 2 reveals a predominance of the more traditional theories. Realism and Liberalism, including their 'neo' versions, are responsible for $29 \%$ and $24 \%$ of the texts, respectively. That is, together, they account for more than half of the texts used to teach International Relations Theory. Following them, Constructivism, the English School and Marxism occupy a relatively smaller, though still significant, portion of the texts. Feminism, Critical Theory and PostModernism are less present, corresponding to less than 5\% of the total each. The category 'others' includes mostly texts about globalization and Foreign Policy Analysis.

It is interesting to note that, in Arlene Tickner's work, published in 2003, the syllabi of both Brazilian universities analyzed by the author (UnB and PUC Rio) contained no texts related to Constructivism, which here appears as corresponding to $9 \%$ of the total. In the case of PUC Rio there were also no texts related to Marxism or Post-Modernism, which now account for

16 This was, of course, done using our judgment and knowledge of the authors and texts. If we had any doubts regarding classification the text was consulted to guarantee that there would be no misclassifications. 
$2 \%$ and $5 \%$ of the texts used in the three IRT courses offered in that institution. It is possible that this growth in participation has come to accompany a growing trend in its prominence in IR debates in general. However, we must take into account that in her study Tickner chose to analyze only one of the IRT courses offered at each institution (normally the introductory course), which probably affected her results.

This configuration of the Brazilian IRT syllabi is related to the fact that, as Monica Herz (2002) points out, the incorporation of IRT paradigmatic debates happened in Brazil mostly from the 1990s onwards, and relatively slowly. This decade was marked by the influence of the debate between neorealists and neoinstitutionalists and by the incorporation of the English School. Moreover, as Herz (2002: 29) argues, hegemony remained in realist hands. In addition to this, language and monetary barriers probably play a role since professors must undoubtedly take into account whether or not students can access and comprehend the texts.

According to Arlene Tickner's study (2003) of IR syllabi in twelve Latin American universities, Brazilian courses follow the regional trend in emphasizing more traditional theories. In Latin-America the average is of 53\% of texts dedicated to Realism, Neorealism or Neoliberalism, while $11 \%$ were dedicated to Liberalism and Interdependence Theory.

Another regional characteristic is that of mostly ignoring endogenous perspectives on IR - such as Dependency theory - in the teaching of IRT. As we show, Brazil follows this profile, with only $2 \%$ of the required readings belonging to what Tickner refers to as "Latin American Thought" ${ }^{17}$. However, it is worth noting that, while it represents a small portion of the total of texts, when we verified how many courses used at least one text related to Latin American Thought, we found that it was actually present in 26\% of the courses. As Mônica Herz (2002: 17) points out, Dependency theory - arguably Latin America's biggest contribution to IRT - became marginalized within IR thought in the 1970 s, during a process of reaffirmation of realist predominance in the field. It is perhaps not surprising, then, that when seeking to build a syllabus around what is currently considered the "canon" of IRT most professors do not include texts on Latin American Thought.

Our analysis shows that, in general, the problem is not the number of courses offered. It must be said, though, that in the case of programs which offer only one course the quality of the teaching is probably compromised and the bibliography tends to be made up of only manuals. Despite being a useful and didactic resource, manuals do not instigate the development of critical analysis skills in the same manner as the engagement with the original texts.

A more substantive problem is the absence in the syllabi of any bibliography that deals with questions such as what is theory, and what are its uses. This kind of resource would be necessary to give the students a better ability to understand theories beyond memorization, to evaluate them critically, to understand their role in research, and to cherish theory as a particular instrument to access and build on IR knowledge proper. We believe this affects how research is conducted in the field of IR in Brazil, which is the subject of the following section.

17 We decided to incorporate the term created by Tickner (2003) in our work. 


\section{International Relations Theory in Brazilian Academic Research}

To evaluate the state of theoretical reflection in the field of International Relations in Brazil, we studied $\mathrm{PhD}$ dissertations, technical reports of research projects financed by $\mathrm{CNPq}$ and papers published in academic journals. We sought to: 1) verify the presence of different theories in the texts analyzed, 2) see if there was a connection between the author's academic background and the use of theory, and 3) compare the use of theory in teaching and in research.

Regarding the quantity and quality of academic research, it was in the 1990s that the field of IR surpassed the mere historical recuperation and foreign policy prescription which had characterized it up until that point. The permeability to theoretical debates that were taking place outside of the country increased, mostly as a result of a greater interaction with American and European research centers, which coincided with the return of professors who had done part of their studies abroad. (Herz, 2002).

To evaluate the participation of public and private institutions in International Relations academic research, we analyzed 68 research projects financed by CNPq and 112 papers published in the two top-rated Brazilian journals in the field (Revista Brasileira de Politica Internacional, or RBPI, and Contexto Internacional) between the years of 2004-2009 ${ }^{18}$. Out of the research projects financed by $\mathrm{CNPq}, 72.4 \%$ were attached to public universities and $27.6 \%$ to private universities. As for the academic papers, we verified whether the primary author had a connection (as faculty or as a student) with a private or public institution. The authors who either worked or studied in a public university totaled $62 \%$, while those in a private university corresponded to $38 \%$.

We also looked at how many of the works collected had theory as their main subject ${ }^{19}$. Out of the 68 technical reports mentioned above, we only had full access to 20. Of those, none had theory as the main subject. The analysis all the articles of RBPI available online (starting in 1997) revealed that out of all the articles published until 2009, only three were dedicated to theory. The journal Contexto Internacional had a larger number of papers related to theory: out of the 115 articles published between 1999-2009, 21 were dedicated to this subject, or $18 \%$ of the total.

To assess the use of different IR theories we analyzed three types of documents: PhD dissertations, technical reports from research projects financed by CNPq, and papers published in RBPI and Contexto Internacional. For the PhD dissertations, we used those defended at the PhD programs at UnB and PUC-Rio, the only programs which had already graduated doctors at the time of this research - this totaled 36 dissertations. Via the Access to Information Law

$18 \mathrm{PhD}$ dissertations were not included because at the time of this research, only two institutions had graduated doctors: UnB, a public university, and PUC Rio, a private university.

19 We consider this to mean that the article is dedicated purely to theory, which excludes, for example, articles which use theory to analyze real world phenomena. Examples of works which were considered to have theory as their main subject are: Revisiting the English School by José Flávio Sombra Saraiva (Rev. Bras. Pol. Int. Vol. 49, n. 1, 2006) and Critical Theory in International Relations by Marco Antonio de Meneses Silva (Contexto Internacional, vol. 27, n. 3, 2005). 
(Lei de Acesso à Informação), we obtained $20 \mathrm{CNPq}$ technical Reports ${ }^{20}$. However, only 12 of those could be used ${ }^{21}$. For the journal articles we used all published in RBPI and Contexto Internacional between 2005-2009, totaling 112 papers $^{22}$.

We made our analysis by reading the abstract, introduction and conclusion of all the works. In the cases of dissertations, we also read the "theoretical chapter" when applicable. When it was still not possible to ascertain which - or if any - theory had been used, we proceeded with a keyword search (the keywords used were: theory, theoretical, perspective, approach, paradigm, concept, realism, realist, liberalism, liberal, constructivism, constructivist, english school, marxism, marxist). The choice of the keywords is related to the most common theories used in teaching (see Table 2).

The results of the research are summarized in Table 3. We would like to highlight that the values correspond to the quantity of works in which a given theory is used, so the sum will, in some cases, be larger than 100. This is explained by the values in the category "more than one", which comprises works that used a combination of two or more theories. Furthermore, we did not consider all the theories that were mentioned (which, especially for the dissertations, could be a rather large number), but the theory(ies) which constituted the theoretical basis for the work in question.

Table 3: Use of Theories in Brazilian Academic Research

\begin{tabular}{|l|c|c|c|c|}
\hline & Dissertations & CNPq Technical Reports & Journals & Total \\
\hline Realism & $9 \%$ & $0 \%$ & $9 \%$ & $8 \%$ \\
\hline Liberalism & $17 \%$ & $8 \%$ & $10 \%$ & $11 \%$ \\
\hline Constructivism & $17 \%$ & $0 \%$ & $12 \%$ & $12 \%$ \\
\hline English School & $6 \%$ & $0 \%$ & $6 \%$ & $6 \%$ \\
\hline Marxism & $0 \%$ & $0 \%$ & $0 \%$ & $0 \%$ \\
\hline Feminism & $3 \%$ & $0 \%$ & $0 \%$ & $1 \%$ \\
\hline Critical Theory & $6 \%$ & $0 \%$ & $2 \%$ & $3 \%$ \\
\hline Post Modernism & $0 \%$ & $0 \%$ & $2 \%$ & $1 \%$ \\
\hline Latin-American Thought & $9 \%$ & $0 \%$ & $3 \%$ & $4 \%$ \\
\hline Copenhagen School & $11 \%$ & $0 \%$ & $2 \%$ & $4 \%$ \\
\hline Other & $48 \%$ & $58 \%$ & $26 \%$ & $33 \%$ \\
\hline None & $14 \%$ & $33 \%$ & $44 \%$ & $37 \%$ \\
\hline More than one & $31 \%$ & $0 \%$ & $11 \%$ & $34 \%$ \\
\hline
\end{tabular}

Source: authors' own elaboration based on dissertations, technical reports and academic papers as indicated in the text.

20 The request was sent to CNPq through the e-SIC (http://www.acessoainformacao.gov.br/sistema/) in September 29th, 2012, receiving the protocol number 01390.000166/2012-94.

21 The others either consisted of reports related to participations in congresses or did not sufficiently describe the research,

22 We only excluded papers published by foreign authors with no formal connection to a Brazilian university. 
Table 3 shows that there are significant differences in the use of theories in different types of research. The dissertations use a larger array of theories, while the researches financed by CNPq almost do not use any of the most traditional IR Schools of Thought, and the journal articles fall somewhere in between. All theories, in fact, are more present in dissertations than in either $\mathrm{CNPq}$ reports or journal articles, which may be due to the fact that dissertations simply use theory - any theory - more than articles and reports, which often don't use any theory at all.

This difference may be due to a combination of two factors. The first is a generational difference. Most of the research financed by CNPq is conducted by professors at traditional Brazilian universities. These professors generally do not have degrees in IR - which is not surprising considering how young the discipline is in Brazil - but come from a variety of disciplines such as History, Economy and Political Science. The expansion of the offer of undergraduate and graduate degrees in IR in the country will probably have a considerably effect on how future research in the field is conducted.

Additionally, there is the fact that dissertations normally contain a "theoretical chapter" in which the author describes the theories that supposedly base the research in question. However, if we consider that articles published in academic journals tend to be, for the most part, the final product of research - that which is shared with the academic community at large - these results make us ponder whether the theory used in $\mathrm{PhD}$ dissertations was central to the research. Unfortunately, there was not a significant sample of papers which had been derived from $\mathrm{PhD}$ dissertations analyzed here. Therefore, we were not able to evaluate if in most cases the theory presented in the dissertation is transported to the journal article.

Another difference among the different types of research is the use of theories other than IR's grand theories or Schools of Thought (the "other" in our Table 3). This category includes mostly middle-range theories 23 (MRTs) and, in some cases, theories from other fields, such as Sociology or Political Science. As can be seen, a good part of the works is based in this type of theory, stepping away from the grand theories that seek to explain the International System as a whole, and rather looking for theories that approach more directly the subject at hand.

An additional result from the comparison between the data from our research and the 2012 TRIP (Teaching, Research and Policy views of International Relations Faculty in 20 countries) ${ }^{24}$ indicates a certain convergence between the two when we consider only the works which do use some theory. However, there are some significant differences. Firstly, we discovered a much larger number of works which fall into the "other" category - even when we sum two of TRIP's categories: "other" and "non-paradigmatic".

23 The concept of middle-range theories (MRT) was initially developed by Robert K. Merton. In his work Social Theory and Social Structure (1968: 39) the author defines MRTs as: "theories that lie between the minor but necessary working hypotheses that evolve in abundance during day-to-day research and the all-inclusive systematic efforts to develop a unified theory that will explain all the observed uniformities of social behavior, social organization and social change”.

24 The TRIP results on this table are answers to the question: "Which of the following best describes your approach to the study of IR? If you do not think of your work as falling within one of these paradigms, please select the category in which most other scholars would place your work" (MALINIAK, Daniel; PETERSON, Susan; TIERNEY, Michael J. 2012: 27). 
Table 4: Comparison between IR theories used in research in Brazil and TRIP results

\begin{tabular}{|c|c|c|c|}
\hline & Total & Total with theory & TRIP \\
\hline Realism & $8 \%$ & $13 \%$ & $14 \%$ \\
\hline Liberalism & $11 \%$ & $18 \%$ & $13 \%$ \\
\hline Constructivism & $12 \%$ & $19 \%$ & $20 \%$ \\
\hline English School & $6 \%$ & $9 \%$ & $9 \%$ \\
\hline Marxism & $0 \%$ & $0 \%$ & $8 \%$ \\
\hline Feminism & $1 \%$ & $1 \%$ & $1 \%$ \\
\hline Other & $45 \%$ & $51 \%$ & $16 \%$ \\
\hline Non-paradigmatic & $\mathrm{x}$ & $\mathrm{X}$ & $19 \%$ \\
\hline None & $37 \%$ & $\mathrm{X}$ & $\mathrm{X}$ \\
\hline
\end{tabular}

Source: authors' own elaboration based on dissertations, CNPq technical reports and academic papers and data by MALINIAK, Daniel; PETERSON, Susan; TIERNEY, Michael J (2012).

Furthermore, the results related to certain theories also differ considerably. The most notable in this aspect is Marxism. While the TRIP survey shows 8\% of professors affirmed that they used this theory as the basis for their work, in our research we did not find any work that used it or even cited it. With regards to Liberalism, the opposite occurs, more researchers use it in our sample than according to the TRIP survey. It is possible that the participants of the TRIP survey answered the question based on which theory they identify with most, which does not necessarily imply the use of said theory in their research practice. This is only a possible explanation, however, and at this time there is not enough data to allow us to affirm this with certainty.

We also sought to evaluate whether there was a relation between the use of theories in research and the authors' academic background. To do so, we divided the texts ${ }^{25}$ between those that used theory and those that did not and consulted the authors' curriculum lattes ${ }^{26}$. The results are shown in Table 5 (below).

Table 5: Relation between the use of theories and the author's academic career

\begin{tabular}{|l|c|c|c|}
\hline Degrees $(\mathbf{B A}, \mathbf{M A}$ or $\mathbf{P h D})$ in IR & \% of Total Authors & Use Theory & Do not use theory \\
\hline No degree in IR & $49 \%$ & $37 \%$ & $62 \%$ \\
\hline One or more degree in IR & $23 \%$ & $31 \%$ & $15 \%$ \\
\hline Two or more degrees in IR & $27 \%$ & $31 \%$ & $23 \%$ \\
\hline Total & $\mathbf{1 0 0}$ & $\mathbf{1 0 0}$ & $\mathbf{1 0 0}$ \\
\hline
\end{tabular}

Source: authors' own elaboration based on academic papers and curriculum lattes, as mentioned in the text.

25 We did not include PhD dissertations in this table because all the authors would necessarily have their PhDs in IR, biasing the results. 26 As available at Plataforma Lattes (http://lattes.cnpq.br/). 
Table 5 shows that those authors who had some stage of their career in IR tended to use more IR theories. Considering the great expansion in IR degrees on offer in Brazil, both in undergraduate and graduate levels, we speculate that this will be an important factor in defining the role of theory in future research.

Table 6 compares the use of different IR theories in teaching and in research. As we show, there are considerable differences between the results ${ }^{27}$.

Table 6: Theories used in teaching and research in Brazil

\begin{tabular}{l|c|c}
\hline & Teaching & Research \\
\hline Realism & $29 \%$ & $13 \%$ \\
\hline Liberalism & $24 \%$ & $18 \%$ \\
\hline Constructivism & $9 \%$ & $19 \%$ \\
\hline English School & $8 \%$ & $9 \%$ \\
\hline Marxism & $9 \%$ & $0 \%$ \\
\hline Feminism & $4 \%$ & $1 \%$ \\
\hline Others & $22 \%$ & $51 \%$ \\
\hline
\end{tabular}

Source: authors' own elaboration based on syllabi, dissertations, technical reports and academic papers, as mentioned in the text.

Firstly, we verified that in teaching there is a predominance of the more traditional theories - the most present being Realism, Liberalism and Marxism. In research, however, the most used theory is Constructivism. It is also noteworthy the quantity of research that uses theories that are not related to the grand Schools of Thought.

One of the reasons for this discrepancy may be of a methodological nature. In her investigation about the use of theories in research in seven Latin American countries, Arlene Tickner (2003: 344) argues that one of the reasons for a smaller use of both Neorealism and Neoliberal Institutionalism is "the absence of a strong quantitative analytical tradition in the region". In Tickner's research, published twelve years ago, the author shows that very few works use Constructivism. However, it is possible that the large use of Constructivism that appears in our own research might have a similar origin, given that many researchers perceive this approach as being more flexible in methodological terms.

The predominance of traditional theories in teaching might demonstrate, for its turn, that the syllabi are not designed to give priority to theories that are seen as more relevant, but are either a reflection of habit, or an attempt to showcase the historical evolution of the discipline. It remains noteworthy, even if we take this last argument into consideration, - that the more traditional Schools of Thought - especially Realism - are not predominant only in the quantity of readings in general, but even more so in the amount of original works (not manuals) assigned

27 In this table, in the Research category, we considered only those works which did use some IR theory. 
to the the students. Again, the lack of Portuguese translations of more recent works probably plays a part in this.

Another fact that draws attention among the results was the use, in a considerable amount of the works analyzed (34\%), of the combination of two or more theories. One of the most common combinations which could be observed was of Realism, Liberalism and Constructivism. The use of several theories in the same work, which can be called theoretical pluralism (Checkel, 2012), or analytical eclecticism (Sil and Katzenstein, 2010) has been a somewhat prominent feature of the academic debate in IR in the last decade. Its defenders, in general, claim that the division of the discipline in different "isms" has stalled its advance. David Lake (2012: 465), for example, argues that "we organize ourselves into academic "sects" that engage in self-affirming research and then wage theological debates between academic religions."

Nonetheless, as Checkel argues (2012: 236), to avoid "an attitude of anything goes" it becomes necessary to pay great attention to methodology and epistemology, for, as Lake (2012: 466) affirms "each research tradition has a unique set of core assumptions about the nature of world politics. These assumptions, in turn, are often incommensurate across traditions." Even Sil and Katzenstein (2012: 484) advert:

Cutting across paradigms is not simply a matter of being pluralistic in attitude. It is also a matter of recognizing how the meta-theoretical priors of a given approach shape the manner in which its adherents view the world, articulate research questions, define core concepts, and develop explanatory or interpretive schemes.

In relation to the works analyzed, it is possible to question to what extent this theoretical eclecticism was conducted in a conscious manner, and did not simply consist of putting different elements from several theories in a "great blender" (Elman and Elman, 2003: 59) with no clear criteria. This evaluation, however, goes beyond the scope of this research, and would require a deeper look into the works in question.

\section{Conclusion}

The field of International Relations in Brazil saw a significant expansion in the last decade, with a considerable increase in the number of undergraduate and -graduate programs. However, the field still faces significant challenges, such as the undefined profile of the undergraduate courses and what we could call the "pragmatic trap" - that is, the tendency to skew syllabi towards what is considered more "practical" and, consequently, more marketable.

In this context, the teaching of theory is not prioritized. Although the number of disciplines offered is mostly acceptable, it is noticeable that the profile of the teaching remains based on the exposition, more or less acritical, of different theories, without any discussion regarding the role of theory in IR and its use as an important tool in research. 
Our analysis of the research in the field indicates a detachment between what is presented in the teaching of IRT and the use of theories in research: while teaching focuses on IR's grand theories - the "isms" - in research a large part of the works do no use any theory at all or use some other type of theory, normally a middle-range theory (MRT) or theories from other fields. While the use of MRTs in research is entirely understandable, it is noteworthy that IRT courses do not include topics on this type of theory and its uses. It is questionable to what extent is that which is taught in IRT courses - retained and how much of it is perceived as being useful, either in research or for future professional careers.

The large number of works that do not cite any type of theory, as well as those that use several theories from different Schools of Thought, seem to indicate the necessity of an ample debate in the field regarding the role of theory in research, its applicability and how to evaluate it. This debate will be crucial not only to improve the conduct of research in general, but also to boost the development of independent theorizing.

\section{Bibliography}

ACHARYA, Amitav; BUZAN, Barry.(2010) Non-Western International Relations Theory: Perspectives on and beyond Asia. New York: Routledge, 253 p.

AYNDILI, Ersel; MATHEWS, Julie. (2000). Are The Core and The Periphery Irreconcilable? The Curious World of Publishing in Contemporary International Relations. Tucson: International Studies Perspectives, n. 1, p. 289-303.

BUZAN, Barry. (2010). Non-Western International Relations Theory: Perspectives on and beyond Asia. New York: Routledge, 253 p.

CERVO, Amado L. (2008) Inserção Internacional: formação de conceitos brasileiros. São Paulo: Saraiva, $297 \mathrm{p}$.

CHECKEL, Jeffrey T. Theoretical Pluralism in IR: Possibilities and Limits. In Walter Carlsnaes,

Thomas Risse, Beth Simmons, Eds. (2012). Sage Handbook of International Relations, 2nd Edition. London: Sage Publications.

DOUGHERTY, James E.; PFALTZGRAFF, Robert L. (1997). Contending theories of international relations a comprehensive survey. New York: Longman.

ELMAN, Colin; ELMAN, Miriam F (eds). (2003). Progress in International Relations Theory: Appraising the Field. Cambridge: MIT Press.

GOLDSTEIN, Judith; KEOHANE, Robert O. (1993). Ideas and Foreign Policy: beliefs, institutions and political change. New York: Cornell University Press, 310 p.

HAGMANN, Jonas; BIERSTEKER, Thomas J. (2014) Beyond the Published Discipline: towards a critical pedagogy of international studies. European Journal of International Relations, vol. 20, n. 2, p. 291-315. 
HERZ, Mônica. (2012). O Crescimento da Área de Relaçôes Internacionais no Brasil. Rio de Janeiro: Contexto Internacional, vol. 24, n. 1.

INEP. Consulta de Informaçóes Educacionais. <http://inepdata.inep.gov.br/>.

JULIÃO, Taís Sandrim. (2009) O Brasil no Mundo e o Mundo no Brasil: a formaçáo de quadros, a produção de conhecimento e a construção da área de Relaçôes Internacionais. 2009. Dissertation (Masters in International Relations) - Instituto de Relações Internacionais, Universidade de Brasília.

LAKE, David. (2009) A. Trips across the Atlantic: theory and epistemology in IPE. Montreal: Review of International Political Economy, vol. 16, p. 47-57.

LAKE, David.. (2012). Why "isms" Are Evil: Theory, Epistemology, and Academic Sects as Impediments to Understanding and Progress. Tucson: International Studies Quarterly, n. 55, p. 465-480.

LESSA, Antônio Carlos. A evolução recente dos estudos e dos programas de pós-graduação em Relações Internacionais no Brasil. Revista ComCiência, [S.1]. <http://www.comciencia.br/ comciencia/handler.php?section=8\&edicao=12\&id=98>. Accessed: 12ago. 2007.

LESSA, Antônio Carlos. (2005). Instituições, atores e dinâmicas do ensino e da pesquisa em Relações Internacionais no Brasil: o diálogo entre a história, a ciência política e os novos paradigmas de interpretação (dos anos 90 aos nossos dias). Brasília: Rev. Bras. Polit. Int. vol. 48, n. 2, p. 169-184.

LIMA, Maria Regina Soares de. (2005). A política externa brasileira e os desafios da cooperação Sul-Sul. Brasília: Rev. Bras. Polit. Int. 48 no 1, p. 24-5.

LIMA, Maria Regina Soares de. Prefácio. In. AMORIM NETO, Octavio. (2012). De Dutra a Lula: a condução e os determinantes da politica externa brasileira. São Paulo: Elsevier.

MALINIAK, Daniel; PETERSON, Susan; TIERNEY, Michael J. (2012). Trip Around The World: Teaching, Research, and Policy Views of International Relations Faculty in 20 Countries. Williamsburg: Institute for the Theory and Practice of International Relations, College of William and Mary.

MEARSHEIMER, John J.; WALT, Stephen M. (2013). Leaving Theory Behind: Why simplistic hypothesis testing is bad for International Relations. European Journal of International Relations, vol. 19, n 3, p. 427-457.

MEC (Ministério da Educação). <http://emec.mec.gov.br>.

MEDEIROS, Marcelo de Almeida et AL. (2012). Teóricos das relaçóes internacionais. São Paulo: Hucitec.

MENDONÇA, Filipe; VELASCO E CRUZ, Sebastião. (2010). O Campo das Relações Internacionais no Brasil: Situação, Desafios, Possibilidades. In: LESSA, Renato. (Org.). Ciência Politica. $1^{\text {a }}$ ed. São Paulo: Anpocs/Barcarolla/Discurso Editorial.

MERTON, Robert K. (1968). Social Theory and Social Structure. New York: The Free Press, 1968. MIYAMOTO, Shiguenoli. (1999). O Estudo das Relações Internacionais no Brasil: o estado do arte. Curitiba: Revista de Sociologia e Politica, n 12, junho 1999. 
NOGUEIRA, João Pontes; MESSARI, Nizar. (2005). Teoria das relaçóes internacionais: correntes $e$ debates. Rio de Janeiro: Campus.

PECEQUILO, Cristina Soreanu. (2005). Introdução às relaçôes internacionais: temas, atores e visóes. Rio de Janeiro: Vozes.

RATHBUN, Brian. (2012). Politics and Paradigm Preferences: The Implicit Ideology of International Relations Scholars. Tucson: International Studies Quarterly, vol. 56, 607-622.

RBPI (Revista Brasileira de Política Internacional). <http://www.scielo.br/scielo.php?script=sci_ serial\&pid=0034-329\&lng=en\&nrm=isso $>$.

SANTOS, Norma Breda dos.(2005). História das Relações Internacionais no Brasil: esboço de uma avaliação sobre a área. São Paulo: História, vol. 24, n. 1, p. 11-39.

SANTOS, Norma Breda dos; FONSECA, Fúlvio Eduardo. (2009). A Pós-Graduação em Relações Internacionais no Brasil. Rio de Janeiro: Contexto Internacional, vol. 31, n. 2.

SIL, Rudra; KATZENSTEIN, Peter J. (2010). Beyond Paradigms: Analytic Eclecticism in the Study of World Politics. New York: Palgrave Macmillan.

SILVA, Guilherme A.; GONÇALVES, Williams. (2005). Dicionário de Relaçóes Internacionais. Barueri, SP: Manole.

SMITH, Steve. (2000). The United States and the Discipline of International Relations: "Hegemonic Country, Hegemonic Discipline". The British Journal of Politics and International Relations. London, vol. 2, n. 3.

TICKNER, Arlene.(2003) Hearing Latin American Voices in International Relations Studies. International Studies Perspectives, Malden MA, n. 4, p. 325-350.

TICKNER, Arlene; WEAVER, Ole. (2009). International Relations Scholarship around the World. New York: Routledge.

TICKNER, Arlene B.; BLANEY, David L. (eds.). (2012). Thinking International Relations Differently. New York, NY: Routledge.

WEAVER, Ole. (1998) The Sociology of a Not So International Discipline: American and European Developments in International Relations. International Organization, n. 52. 